\title{
A review of the effect of autumn nitrogen fertiliser on pasture nitrogen concentration and an assessment of the potential effects on nitrate leaching risk
}

\author{
M. SHEPHERD and G. LUCCI \\ AgResearch, Private Bag 3123, Hamilton \\ mark.shepherd@agresearch.co.nz
}

\begin{abstract}
The aim was to test the hypothesis that nitrogen $(\mathrm{N})$ fertiliser applied in autumn increases $\mathrm{N}$ leaching by increasing pasture $\mathrm{N}$ concentration (Nconc) and thus increasing partitioning of excretal $\mathrm{N}$ to urine. A review of past data showed that $\mathrm{N}$ fertiliser application generally had only a small effect on pasture Nconc, on average. The general effect was $\pm 5 \%$ or less for single applications of $50 \mathrm{~kg} \mathrm{~N} / \mathrm{ha}$ or less, compared with nil $\mathrm{N}$ fertilised pasture, depending on the season. Based on this, we estimated that the increase in pasture Nconc from autumn fertiliser is less important for nitrate leaching risk than the extra forage grown, and the resultant extra $\mathrm{N}$ consumed and excreted as a result of the applied fertiliser N. However, if the period between fertiliser application and grazing is short, the elevation in Nconc is likely to be larger with a greater influence on partitioning to urinary $\mathrm{N}$.
\end{abstract}

Keywords: Nitrogen, fertiliser, pasture nitrogen concentration, urine

\section{Introduction}

The general exponential relationship between nitrogen (N) inputs and leaching of $\mathrm{N}$ is well recognised. New Zealand pasture data assembled by Ledgard et al. (2009) shows disproportionally more $\mathrm{N}$ leached as $\mathrm{N}$ inputs increase. Much of this is due to increased loss via the urine patch, as a consequence of the increase in forage grown and consumed and thus in $\mathrm{N}$ excreted. Nitrogen concentration in the diet is also important; the higher the $\mathrm{N}$ concentration in feed, the larger the proportion of excretal $\mathrm{N}$ that is urine $\mathrm{N}$ (Castillo et al. 2000). Fertiliser $\mathrm{N}$ is often applied in the autumn to provide a boost of dry matter (DM) production late in the season. Because urine deposition in the autumn is critical to $\mathrm{N}$ leaching, the interaction between $\mathrm{N}$ inputs, pasture consumed and its $\mathrm{N}$ concentration, and urine deposition at this time should be critical. We hypothesised that $\mathrm{N}$ applied in autumn could increase pasture $\mathrm{N}$ concentration so that disproportionately more $\mathrm{N}$ would be excreted as urine in a critical period for $\mathrm{N}$ leaching risk.

\section{Methods}

An N trials database (Rajendram et al. 2009) has been created with fertiliser industry funding containing results of all pasture $\mathrm{N}$ response trials undertaken between the 1930s and 1990s by AgResearch and its previous organisations. The trials database included 624 treatments where pasture $\mathrm{N}$ concentration as a percentage of DM (Nconc) had been reported, which covered a range of experimental designs, locations, $\mathrm{N}$ fertiliser rates and $\mathrm{N}$ fertiliser products. We used the data to explore trends in pasture Nconc variation and to undertake an analysis of the effects of season and $\mathrm{N}$ rate on pasture Nconc.

The implications of the changes in pasture Nconc with autumn-applied $\mathrm{N}$ fertiliser were then estimated by constructing a spreadsheet model (Figure 1). The basis of the calculation was that the proportion of excretal $\mathrm{N}$ as urine is related to the Nconc of the diet, derived from a review of New Zealand and overseas data (Ledgard et al. 2003):

Proportion of excreta as urine $=29.9+(11.9 \times \% \mathrm{~N}$ of forage $)$

The sensitivity of urinary $\mathrm{N}$ production to pasture Nconc was tested using this spreadsheet model with the following assumptions for grazing dairy cows:

- A single fertiliser $\mathrm{N}$ application of $35 \mathrm{~kg} \mathrm{~N} / \mathrm{ha}$

- DM response $245 \mathrm{~kg} / \mathrm{ha}$ resulting from the fertiliser $\mathrm{N}$ application (fertiliser $\mathrm{N}$ response rate in the autumn of $7 \mathrm{~kg} \mathrm{DM} / \mathrm{kg} \mathrm{N}$; Anon. 2008)

- Grazing at a cover of $2700 \mathrm{~kg} \mathrm{DM} / \mathrm{ha}$ to a residual of $1600 \mathrm{~kg} \mathrm{DM} / \mathrm{ha}$, i.e., $1100 \mathrm{~kg} / \mathrm{ha}$ dry matter intake (DMI)

- Extra pasture grown is able to be utilised

- $70 \%$ of dietary $\mathrm{N}$ intake excreted (i.e., $30 \%$ to milk and meat); within the range of $60-90 \%$ summarised by Haynes \& Williams (1993)

- Urinary $\mathrm{N}$ load then becomes excretal load multiplied by the proportion as urine from equation [1]

The model was run for a baseline pasture Nconc of $4.5 \% \mathrm{~N}$. The effects on urinary $\mathrm{N}$ deposition were calculated for 0 and $5 \%$ increase in pasture $\mathrm{Nconc}$ (i.e., 


\begin{tabular}{|c|c|c|c|c|c|}
\hline \multirow[t]{6}{*}{ Input data } & target cover & 2700 & kg DM/ha & & \\
\hline & target residual & 1600 & $\mathrm{~kg} \mathrm{DM} / \mathrm{ha}$ & & \\
\hline & proportion excreted & 0.7 & & & \\
\hline & $\mathrm{N}$ rate & 35 & $\mathrm{~kg} \mathrm{~N} / \mathrm{ha}$ & & \\
\hline & DM response rate & 7 & $\mathrm{~kg} \mathrm{DM} / \mathrm{kg} \mathrm{N}$ & & \\
\hline & baseline $\% \mathrm{~N}$ & 4.5 & $\%$ & & \\
\hline \multirow{3}{*}{$\begin{array}{l}\text { Calculated } \\
\text { production }\end{array}$} & DM from fertiliser $\mathrm{N}$ & 245 & & & \\
\hline & nil N yield & 855 & \multicolumn{3}{|c|}{ Scenario: effect of $\mathrm{N}$ fert on pasture $\% \mathrm{~N}$} \\
\hline & & & $0 \%$ increase & $5 \%$ increase & $10 \%$ increase \\
\hline \multirow[t]{6}{*}{ Fertilised pasture } & yield (kg/ha) & 1100 & & & \\
\hline & $\mathrm{N}$ concentration & $\%$ & 4.5 & 4.73 & 4.95 \\
\hline & $\mathrm{N}$ consumed & $\mathrm{kg} \mathrm{N} / \mathrm{ha}$ & 50 & 52 & 54 \\
\hline & $\mathrm{N}$ excreted & $\mathrm{kg} \mathrm{N} / \mathrm{ha}$ & 35 & 36 & 38 \\
\hline & prop urinary $\mathrm{N}$ & $\%$ & 83 & 86 & 89 \\
\hline & urinary $\mathrm{N}$ & $\mathrm{kg} \mathrm{N} / \mathrm{ha}$ & 29 & 31 & 34 \\
\hline \multirow{7}{*}{ Nil fertilised } & & & & & \\
\hline & yield ( $\mathrm{kg} / \mathrm{ha}$ ) & 855 & & & \\
\hline & $\% \mathrm{~N}$ & & 4.5 & & \\
\hline & $\mathrm{N}$ consumed & $\mathrm{kg} \mathrm{N} / \mathrm{ha}$ & 38 & & \\
\hline & $\mathrm{N}$ excreted & $\mathrm{kg} \mathrm{N} / \mathrm{ha}$ & 27 & & \\
\hline & prop urinary $\mathrm{N}$ & $\%$ & 83 & & \\
\hline & urinary $\mathrm{N}$ & $\mathrm{kg} \mathrm{N} / \mathrm{ha}$ & 22 & & \\
\hline
\end{tabular}

Figure 1 Layout of spread sheet model to estimate the effects of pasture $\% \mathrm{~N}$ concentration on excretal loads.

from $4.5 \% \mathrm{~N}$ to 4.5 or $4.73 \%$, respectively) as a result of fertiliser application (as well as a yield increase), for comparison with applying no fertiliser. A third scenario was run to simulate the effects of a shortened spelling period whereby the pasture was grazed 2 weeks after $\mathrm{N}$ application. It was assumed that the pasture Nconc was elevated by $20 \%$ because there was insufficient time for growth to dilute the $\mathrm{N}$ uptake phase, but also that DMI would be less due to the shorter growing period.

Table 1 Estimated effects of changes in pasture $\mathrm{N}$ concentration and dry matter production arising from a single $\mathrm{N}$ fertiliser application in autumn for a baseline (nil $\mathrm{N}$ fertilised) pasture $\mathrm{N}$ concentration of $4.5 \%$.

\begin{tabular}{|c|c|c|c|c|c|}
\hline & & \multicolumn{4}{|c|}{ Scenario } \\
\hline & & nil $N$ & \multicolumn{2}{|c|}{ Fertiliser $\mathbf{N}$} & $\begin{array}{c}\text { Fertiliser } \mathrm{N} \\
+ \text { short spelling }\end{array}$ \\
\hline \multicolumn{6}{|l|}{ Pasture } \\
\hline Base $\mathrm{N}$ concentration & $(\%)$ & 4.5 & & & \\
\hline Increase in Nconc & (\%) & & 0 & 5 & 20 \\
\hline $\mathrm{N}$ concentration & $(\%)$ & 4.5 & 4.5 & 4.7 & 5.4 \\
\hline $\mathrm{N}$ response & $(\mathrm{kg} \mathrm{DM} / \mathrm{kg} \mathrm{N})$ & & $7: 1$ & $7: 1$ & $5: 1^{1}$ \\
\hline DM yield & (kg DM/ha) & 855 & 1100 & 1100 & 625 \\
\hline $\mathrm{N}$ eaten & (kg N/ha) & 38 & 50 & 52 & 34 \\
\hline \multicolumn{6}{|l|}{ Excreta } \\
\hline $\mathrm{N}$ excreted & (kg N/ha) & 27 & 35 & 36 & 24 \\
\hline Proportion as urine & $(\%)$ & 83 & 83 & 86 & 94 \\
\hline Urine & (kg N/ha) & 22 & 29 & 31 & 22 \\
\hline
\end{tabular}

\footnotetext{
${ }^{1}$ Lower response rate assumed for the first grazing round due to the shortened spelling period.
} 


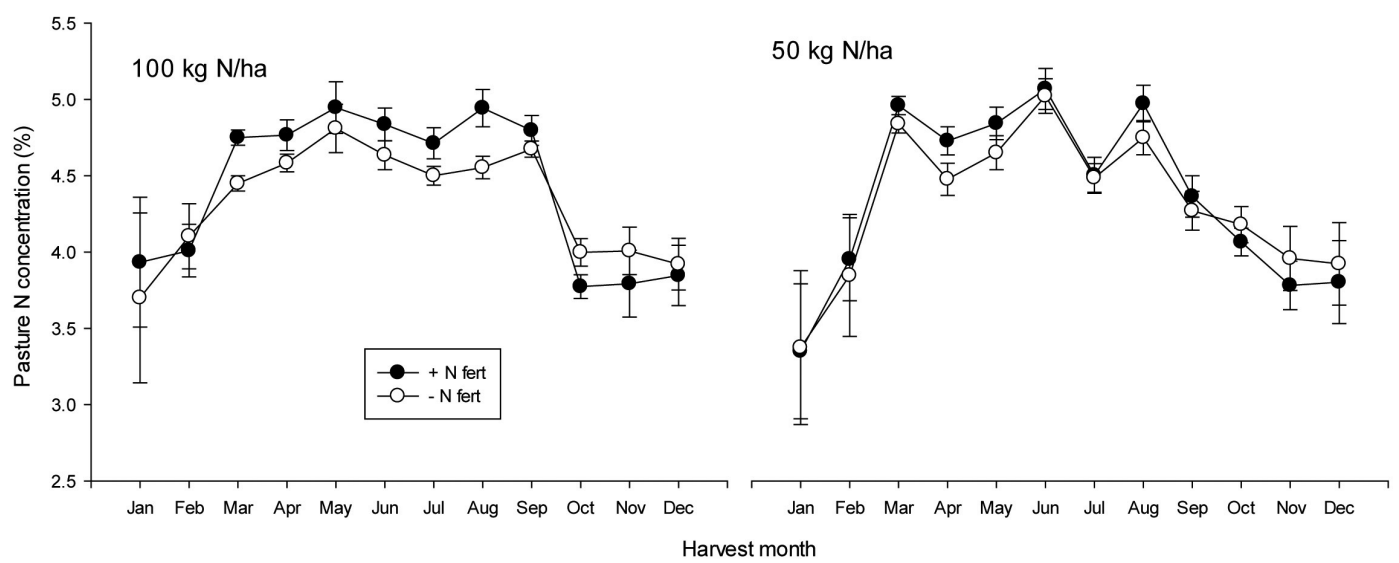

Figure 2 Seasonal variation in pasture $\mathrm{N}$ concentration, for nil fertiliser $\mathrm{N}$ and 100 or $50 \mathrm{~kg} \mathrm{~N} / \mathrm{ha}$ treatments, from the $\mathrm{N}$ trials database. Error bars show the SEM.

\section{Results}

\section{Pasture N concentration}

Experiments that received nil, 50 or $100 \mathrm{~kg} \mathrm{~N} / \mathrm{ha}$ as a single dressing were extracted from the database. Pastures were mainly grass/white clover mixes and we restricted the data to spelling periods that were appropriate for grazing rounds. Although variable between experiments, on average there was seasonal variation in Nconc in the absence of fertiliser N (Figure 2 ), with highly significant differences between months $(\mathrm{P}<0.001)$. Lowest concentrations were in January, highest were in May, June and August. Seasonally, pasture Nconc was highest in the autumn/winter and lower in late spring/early summer (Figure 2).

There was also a seasonal effect on pasture Nconc when fertiliser was applied, with a significant effect of month $(\mathrm{P}<0.001)$ on Nconc for both 50 and $100 \mathrm{~kg} \mathrm{~N} /$ ha applied as a single dressing (Figure 2). For both application rates, there was also a highly significant effect of month on the difference in Nconc between fertilised and control treatments $(\mathrm{P}<0.01)$. Figure 2 suggests higher Nconc with $\mathrm{N}$ fertiliser in the autumn-early spring months and the same or lower concentrations in late spring/early summer. However, the differences were relatively small. The difference in pasture Nconc, on average (expressed as a percentage of the nil-N control) was in the range $2-6 \%$ for application rates up to $100 \mathrm{~kg} \mathrm{~N} / \mathrm{ha}$ in the period March-May.

\section{Estimated effects of pasture $\mathbf{N}$ concentration on autumn urinary $\mathrm{N}$ load}

Table 1 shows the estimations of consumed $\mathrm{N}$, the proportion of excreta that would be urine and the urinary $\mathrm{N}$ load using a baseline (i.e., nil fertilised pasture) Nconc of $4.5 \%$; the latter was in line with the average pasture Nconc in April in the $\mathrm{N}$ trials database
(Figure 2). Nitrogen eaten increased with fertiliser $\mathrm{N}$ as a result of increased DM production and increased Nconc (Table 1). This assumes that stocking rate and/or grazing management is adjusted to utilise the extra pasture. Urinary $\mathrm{N}$ load increased as a result of increased $\mathrm{N}$ intake and increased partitioning to urine. Increasing pasture Nconc increased the proportion of excreta as urine, from equation [1]. A 5\% increase in Nconc resulted in an additional $2-3 \%$ partitioning to urine for the scenarios tested.

At $4.5 \%$ base Nconc, by comparing the calculated urinary $\mathrm{N}$ load from unfertilised and fertilised pasture but with no increase in pasture Nconc, we estimate that there is a $c a .30 \%$ increase in urinary $\mathrm{N}$ load (29 vs $22 \mathrm{~kg} \mathrm{~N} / \mathrm{ha}$ ), which is entirely due to increased DM production and consumption. If this calculation is repeated, but assuming there is a $5 \%$ increase in baseline Nconc due to fertiliser (31 vs $22 \mathrm{~kg} \mathrm{~N} / \mathrm{ha}$ ), urinary $\mathrm{N}$ load increases by $c a .40 \%$, compared with the unfertilised pasture. Thus, we can estimate that $75 \%$ of the increase in urinary $\mathrm{N}$ load is derived from increased DMI and 25\% from increased pasture Nconc.

This assumes an adequate spelling period to produce sufficient growth to dilute the extra $\mathrm{N}$ uptake (see Discussion). The final scenario in Table 1 therefore assumes the farm needs the feed earlier so that the pasture Nconc is still elevated. Based on the same modelling approach, we estimate a greater partitioning of excreted $\mathrm{N}$ to urinary $\mathrm{N}$. However, because there is less growth at the first round of grazing, less $\mathrm{N}$ eaten is than in the first two scenarios and the increased effect of pasture Nconc on urinary $\mathrm{N}$ partitioning is negated by a smaller $\mathrm{N}$ intake. 


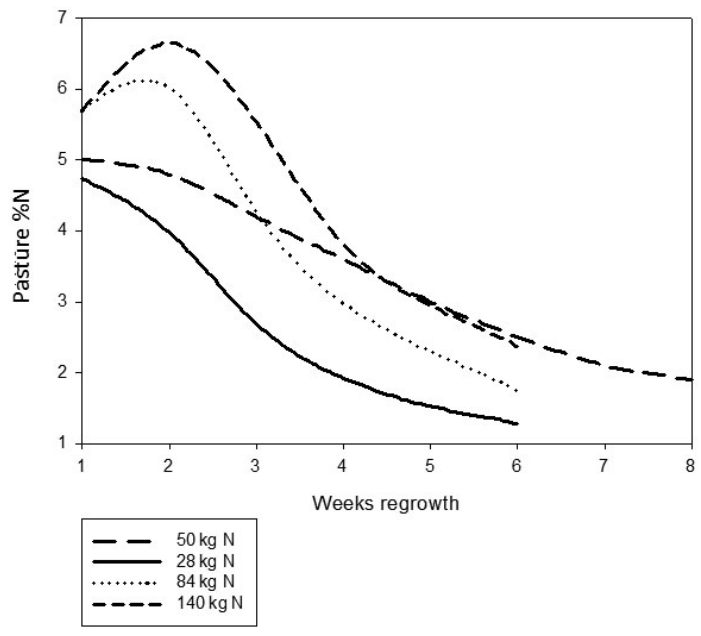

Figure 3 The change with time in pasture $\mathrm{N}$ concentration (\%) after application of $\mathrm{N}$ fertiliser (From Ball \& Field 1982 (50kg N/ha to ryegrass-white clover) and Wilman $1965(28-140 \mathrm{~kg} \mathrm{~N} / \mathrm{ha}$ to Italian Ryegrass)).

\section{Discussion}

There is seasonal variation in pasture Nconc. The highest concentrations were measured from late autumn to early spring, while the lowest are usually measured in late spring. The seasonal variation of Nconc found in the data is also supported by other New Zealand research; farms in the Waikato, Hawke's Bay, Wairarapa, Tararua, Manawatu, and Southland regions sampled for 1 year or more had the highest concentrations of $\mathrm{N}$ in the autumn to early spring period (McNaught \& Dorofaeff 1968; Metson 1978; Moller et al. 1996; Litherland et al. 2002; Machado et al. 2005).

However, the main aim was to test the hypothesis that $\mathrm{N}$ fertiliser applied in autumn would result in higher $\mathrm{N}$ concentrations in pasture, compared to $\mathrm{N}$ applied in other seasons. The evidence from a collection of trials generally supports this hypothesis. There was generally a significant $(\mathrm{P}<0.001)$ effect of fertiliser $\mathrm{N}$ addition on pasture Nconc compared with the nil-N treatment. Effects of $\mathrm{N}$ fertiliser on pasture Nconc were generally positive in autumn/winter and sometimes negative (i.e., control $>\mathrm{N}$ fertiliser) in late spring/early summer. However, critically, the effects of $\mathrm{N}$ fertiliser were relatively small, generally $<6 \%$ increase in Nconc above the nil-N control. We looked at trial data from 50 and $100 \mathrm{~kg} \mathrm{~N} / \mathrm{ha}$ as single dressings, however $50 \mathrm{~kg} \mathrm{~N} /$ ha or less would be more typical of single applications (Shepherd 2009). On an annual basis, Wilman \& Wright (1983) found that the mean increase of applied $\mathrm{N}$ for 32 data sets was $8 \%$ and $17 \%$ above the control $(+0.16$ and $0.40 \% \mathrm{~N}$ units) when $100 \mathrm{~kg} \mathrm{~N} / \mathrm{ha}$ or $200 \mathrm{~kg} \mathrm{~N} / \mathrm{ha}$ was applied annually - which is in general agreement with our data.
The variation in observed Nconc can be due to differences in growth rates and the effects of dilution (Gao et al. 1990). Ball \& Field (1982) and Wilman (1965) noted there was a gradual decline in pasture Nconc with time at lower $\mathrm{N}$ rates $(28$ and $50 \mathrm{~kg} \mathrm{~N} / \mathrm{ha}$, which are more akin to typical single applications), while at the much higher rates ( 84 and $128 \mathrm{~kg} \mathrm{~N} / \mathrm{ha}$ ), peak Nconc was reached 2-3 weeks after application (Figure 3). This is critical to our analysis.

\section{Estimated effects of pasture $\mathbf{N}$ concentration on autumn urinary $\mathrm{N}$ load}

Pasture Nconc tends to be higher in the autumn/winter, which is a critical period for $\mathrm{N}$ leaching. Any fertiliser $\mathrm{N}$ effects in addition to this would exacerbate leaching risk. Our calculation shows that extra urinary $\mathrm{N}$ will be deposited from autumn $\mathrm{N}$ fertiliser applications. In reality, this extra $\mathrm{N}$ consumed and deposited will result from both extra DM production and an increase in pasture Nconc. However, we suggest that the majority of this increase is attributable to the increased DM production, certainly if the increase in pasture Nconc is of the order of $5 \%$, as was indicated from our review. This assumes that there has been sufficient time between $\mathrm{N}$ application and grazing for the $\mathrm{N}$ effect to be diluted by extra DM production (which was the case in the trials (Figure 2)). Recognising that a farm may need feed earlier than this, the third scenario indicated that the decreased $\mathrm{N}$ intake would negate the elevated Nconc effect. Although we set the scenario up as for a dairy farm, given that Equation 1 was developed for all ruminants, then the general principles should hold for other species.

The practical implications of this review are:

- Use small doses of $\mathrm{N}$ fertiliser and/or long spelling periods to minimise effects on pasture Nconc, especially in the autumn.

- Substitute low N supplements for pasture to reduce urinary $\mathrm{N}$ load in the autumn.

We assumed that $70 \%$ of consumed $\mathrm{N}$ was excreted and that this proportion was fixed. Changing this value in the model changes the absolute amounts of urinary $\mathrm{N}$ production but does not change the relativity between comparisons. It could be argued that the proportion should change if the same amount of DM is consumed but with different Nconcs, because the $\mathrm{N}$ removal in milk will remain fairly constant. However, sensitivity tests with the model suggest that this had only a small effect in the range of scenarios reported here.

\section{Conclusions}

Nitrogen fertiliser application generally has only a small effect $(<5 \%)$ on pasture $\mathrm{N}$ concentration. A simple spreadsheet model suggested that the effect 
of $\mathrm{N}$ fertiliser on $\mathrm{N}$ leaching risk is due mainly to an increase in the amount of pasture grown and consumed, and subsequently an increase in excretal amount, with a smaller effect on increased partitioning to urine. Further research is required to confirm these findings, which are based on some broad assumptions, and to understand the complex interactions between $\mathrm{N}$ fertiliser application, growth and other site factors.

\section{ACKNOWLEDGEMENTS}

This work was funded by New Zealand dairy farmers through DairyNZ.

\section{REFERENCES}

Anon. 2008. Nitrogen - Principles of applying nitrogen fertiliser to Pasture. DairyNZ. Farm Fact 7-1. http://www.dairynz.co.nz/page/pageid/2145861419 Updated November 2008.

Ball, P.R.; Field, T.R.O. 1982. Responses to nitrogen as affected by pasture characteristics, season, and grazing management. pp. 65-76. In: Nitrogen fertilisers in New Zealand agriculture. Ed. Lynch, P.B. New Zealand Institute of Agricultural Science, Wellington.

Castillo, A.R.; Kebreab, E.; Beever, D.E.; France, J. 2000. A review of efficiency of nitrogen utilisation in lactating dairy cows and its relationship with environmental pollution. Journal of Animal and Feed Sciences 9: 1-32.

Gao, H.; Clark, D.A.; Anderson, C.B. 1990. Herbage accumulation rates and tiller demography of North Island New Zealand hill country pastures. New Zealand Journal of Agricultural Research 33: 225-236.

Haynes, R.J.; Williams, P.H. 1993. Nutrient cycling and soil fertility in the grazed pasture ecosystem. Advances in Agronomy 49: 119-199.

Ledgard, S.; Schills, R.; Eriksen, J.; Luo, J. 2009. Environmental impacts of grazed clover/grass pastures. Irish Journal of Agricultural and Food Research 48: 209-226.

Ledgard, S.; Luo, J.; Monaghan, R. 2003. Partitioning of excreta nitrogen from grazing animals into urine and dung nitrogen. Report for MAF. 14 pp.
Litherland, A.J.; Woodward, S.J.R.; McDougal, D.B.; Boom, C.J.; Stevens, D.R.; Knight, T.L.; Lambert, M.G. 2002. Seasonal variations in pasture quality on New Zealand sheep and beef farms. Proceedings of the New Zealand Society of Animal Production 62: 138-142.

Machado, C.F.; Morris, S.T.; Hodgson, J.; Fathalla, M. 2005. Seasonal changes of herbage quality within a New Zealand beef cattle finishing pasture. New Zealand Journal of Agricultural Research 48: 265-270.

McNaught, K.J.; Dorofaeff, F.D. 1968. Effect of magnesium fertilisers and season on levels of inorganic nutrients in a pasture on Hamilton clay loam. New Zealand Journal of Agricultural Research 11: 551-559.

Metson, A.J. 1978. Seasonal variations in chemical composition of pasture II. Nitrogen, sulphur, and soluble carbohydrate. New Zealand Journal of Agricultural Research 21: 355-364.

Moller, S.N.; Parker, W.J.; Edwards, N.J. 1996. Withinyear variation in pasture quality has implications for dairy cow nutrition. Proceedings of the New Zealand Grassland Association 57: 173-177.

Rajendram, G.S.; Waller, J.; Cameron, C.; Longhurst, R.; Luo, J.; Ghani, A.; O'Connor, M. 2009. Nitrogen fertiliser trial database: a valuable resource. Climatic factors and first cut response to nitrogen application. pp. 191-204. In: Occasional Report No. 22, Nutrient management in a rapidly changing world. Eds Currie, L.D.; Lindsay, C.L. Massey University, Palmerston North, NZ.

Shepherd, M. 2009. Identifying the decision making processes for application of $\mathrm{N}$ fertiliser to an individual paddock. pp. 352-362. In: Occasional Report No. 22, Nutrient management in a rapidly changing world. Eds Currie, L.D.; Lindsay, C.L. Massey University, Palmerston North, NZ.

Wilman, D. 1965. The effect of nitrogenous fertilizer on the rate of growth of Italian ryegrass. Grass and Forage Science 20: 248-254.

Wilman, D.; Wright, P.T. 1983. Some effects of applied nitrogen on the growth and chemical composition of temperate grasses. Herbage Abstracts 53: 387-393. 
